\title{
Seroprevalence of hepatitis $B$ and $C$ among barbers and their clients in the Rabat region of Morocco
}

\author{
I. Belbacha, ${ }^{1}$ I. Cherkaoui, ${ }^{2}$ M. Akrim, ${ }^{3}$ K.E. Dooley ${ }^{4}$ and R. El Aouad ${ }^{5}$
}

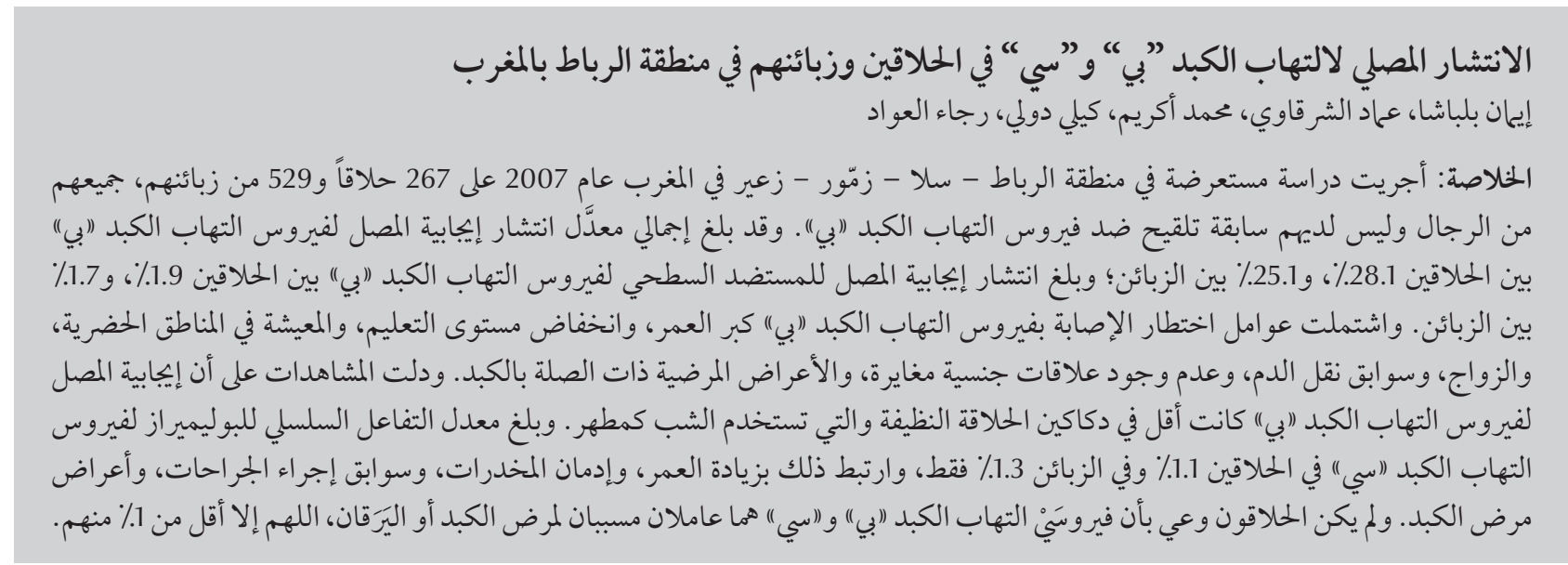

ABSTRACT A cross-sectional seroepidemiological study was conducted in the Rabat-Salé-Zemmour-Zaër region of Morocco in 2007 among 267 barbers and 529 clients, all men with no history of hepatitis B (HBV) vaccination. The overall prevalence of HBV seropositivity was $28.1 \%$ in barbers and $25.1 \%$ in clients; $1.9 \%$ and $1.7 \%$ respectively had active HBV (HBsAg positive). Risk factors for HBV included older age, low educational level, urban living, being married, history of transfusion, lack of current heterosexual relationship and liver-associated symptoms. Observations showed that HBV seropositivity was lower in clean barbershops and those using alum as an antispetic. The rate of PCR-confirmed hepatitis C virus (HCV) was only $1.1 \%$ and $1.3 \%$ in barbers and clients respectively, and was associated with increased age, drug use, history of surgery and symptoms of liver disease. Less than 1\% of barbers were aware of HBV or HCV as causative agents of liver disease or jaundice.

\section{Séroprévalence de l'hépatite B et C chez les barbiers et leurs clients dans la Région de Rabat (Maroc)}

RÉSUMÉ Une étude séro-épidémiologique transversale a été menée dans la Région de Rabat-Salé-ZemmourZaër (Maroc) en 2007 auprès de 267 barbiers et 529 clients. Aucun d'entre eux n'avait été vacciné contre I'hépatite B. La prévalence globale de la séropositivité pour l'hépatite B était de 28,1 \% chez les barbiers et 25,1\% chez les clients ; $1,9 \%$ et 1,7\% d'entre eux respectivement étaient porteurs d'une infection active par le virus de I'hépatite B (Ag HBs positifs). Les facteurs de risque pour le virus de I'hépatite B comprenaient un âge avancé, un niveau d'études faible, un lieu de résidence urbain, le fait d'être marié, des antécédents de transfusion sanguine, l'absence de relation hétérosexuelle au moment de l'étude et la présence de symptômes hépatiques. Les observations ont révélé que la séropositivité pour l'hépatite B était plus faible dans les établissements propres et dans les salons utilisant de l'alun en antiseptique. Le taux des infections par le virus de l'hépatite C confirmées par amplification génique (PCR) était de seulement 1,1\%, et 1,3\% chez les barbiers et les clients, respectivement, et était associé à un âge avancé, la consommation de drogues, des antécédents de chirurgie et les symptômes d'une affection hépatique. Moins d'un pour cent (1\%) des barbiers savaient que les virus de l’hépatite B et C étaient des agents pathogènes des affections hépatiques et des ictères.

${ }^{7}$ AIDS and Hepatitis Unit, Department of Immunology and Virology; ${ }^{2}$ Department of Epidemiology; ${ }^{3}$ Molecular Biology Laboratory, ${ }^{5}$ Directorate, National Institute of Hygiene, Rabat, Morocco (Correspondence to I. Belbacha: Imanbelbacha@yahoo.fr).

${ }^{4}$ Divisions of Clinical Pharmacology and Infectious Diseases, Center for Tuberculosis Research, Johns Hopkins University School of Medicine, Baltimore, Maryland, United States of America.

Received: 13/12/09; accepted: 25/05/10 


\section{Introduction}

Hepatitis B (HBV) and C virus (HCV) infections are a serious global public health problem $[1,2]$. They are leading causes of chronic hepatitis, cirrhosis and hepatocellular carcinoma $[3,4]$. Worldwide, 2 billion people have been infected with HBV over their lifetime; of these, more than 350 million have chronic infection [2]. An estimated 170 million persons are chronically infected with $\mathrm{HCV}$, and 3 to 4 million are newly infected each year [1]. Although treatment regimens exist for $\mathrm{HBV}$ and $\mathrm{HCV}$, their efficacy is suboptimal, and problems with the cost and availability limits their use in low-resource settings [5]. Therefore, prevention is the best, and sometimes only, strategy for combatting $\mathrm{HBV}$ and $\mathrm{HCV}$. HBV vaccination is $95 \%$ effective in preventing HBV, but there is currently no effective vaccine against $\mathrm{HCV}$.

In Morocco, $\mathrm{HBV}$ vaccination was introduced in 1999, and today, over $90 \%$ of infants are vaccinated. However, adults are still at risk for both $\mathrm{HBV}$ and HCV. In particular, acquisition and transmission of bloodborne pathogens has been shown to be an occupational risk among traditional barbers in many countries [6-12]. In Morocco, barbers are commonly exposed inadvertently to the blood and body fluids of their customers $[13,14]$. The objectives of our study were to determine the prevalence of HBV and HCV among traditional barbers and their clients in the Rabat region of Morocco, to determine their risk factors for HBV and HCV and to assess their knowledge of this occupational risk.

\section{Methods}

\section{Study design and sample}

A cross-sectional epidemiological study evaluating risk factors for HBV and HCV and seropositivity for these viruses was conducted during 2007 in traditional barbershops in the Rabat-Salé-Zemmour-Zaër region of Morocco. Men who provide traditional barber services were identified and enrolled in the study, and 2 clients who received services from each barber were also enrolled.

To be able to estimate the seroprevalence of HBV among barbers and clients with a precision of $5 \%$, given a population prevalence of HBsAg among blood donors of $3 \%$ and a barber:client ratio of $1: 2$, we estimated that we would need to enrol 286 traditional barbers and 571 clients. Participants were chosen from 3 provinces in this region. Barbers providing shaving and haircut services at rotating daily open markets in rural areas or at standing but unregistered barbers shops in periurban or urban areas were chosen for the study. Specifically, in Khemisset, a rural province, all barbers were invited to participate. In Salé and Témara-Skhirat, urban provinces, barbers in areas of low socioeconomic level were chosen preferentially.

\section{Data collection}

Questionnaires were administered by trained study personnel to elucidate the medical and socioeconomic risk factors for hepatitis. The questionnaire was supplied by the World Health Organization Eastern Mediterranean Regional Office (EMRO). It was designed and tested for a multi-country project on hepatitis in Egypt, Pakistan and Morocco as part of the Special Programme for Research and Training in Tropical Diseases (TDR) $[7,11]$. Some minor adaptations wee made to suit the local context. In addition, a subset of barbers and clients were observed under routine conditions to evaluate the conditions of their shops and their shaving practices.

Serum hepatitis tests including hepatitis B surface antigen (HBsAg), hepatitis B surface antibody (anti-HBs), hepatitis B core antibody (anti-HBc) and hepatitis $\mathrm{C}$ antibody (anti-HCV) were performed. Polymerase chain reaction (PCR) assay was performed on samples from subjects with positive anti-HCV tests to detect hepatitis C viral RNA for confirmation of HCV infection.

Subjects with positive serological tests were referred to the university hospital in Rabat for further evaluation and treatment. This study was approved by the Directorate of Epidemiology and Disease Control of the Ministry of Health of Morocco. All subjects gave written informed consent for participation.

\section{Definitions}

HBV seropositivity was defined as a positive HBsAg or anti-HBs test, indicating past or current infection with $\mathrm{HBV}$ in this unvaccinated population. Subjects with a positive anti-HCV test confirmed by PCR were considered to have current active hepatitis $\mathrm{C}$.

\section{Serological testing}

Blood samples were centrifuged at provincial laboratories, and serum samples were transported to the $\mathrm{Na}$ tional Institute of Hygiene and stored at $-20^{\circ} \mathrm{C}$ until analysis. HBsAg, anti-HBs and anti-HBc infection markers were determined using commercially available enzyme-linked immunosorbent assays (ELISA) (Dia Pro Diagnostic Bioprobes). Samples that were positive by ELISA were confirmed by the neutralization test according to the manufacturer's instructions. Antibodies to HCV were tested using ELISA (Diagnostic Bioprobes). For those with a positive test, HCV RNA by reverse transcription was performed to confirm HCV infection (Cobas Ampliprep/ Cobas Amplicor).

\section{Statistical analysis}

Data analyses were performed in EpiInfo, version 3.3.2, except for multivariate logistic regressions, which were performed using STATA software, version 10.0 (StataCorp LP). Demographic, medical and shop characteristics were compared using Pearson chi-squared 
or Fisher exact tests for categorical variables. Because there were no significant differences in $\mathrm{HBV}$ and HCV seromarker positivity comparing barbers with clients, these groups were combined for the purposes of $\mathrm{HBV}$ and HCV risk factor analysis. Variables known to be risk factors for $\mathrm{HBV}$ as well as factors found to be associated with $\mathrm{HBV}$ in univariate analyses were included in a multivariable logistic regression model. Multivariable logistic regression analysis was not performed for HCV seropositivity because of the low number of cases. Significance tests were 2 -sided, with $P$-values of $<0.05$ considered statistically significant.

\section{Results}

\section{Population and shop characteristics}

A total of 267 barbers and 529 clients were identified and included in the study. Of the barbers, 75 (28.1\%) were seropositive for HBV and 3 (1.1\%) were positive for HCV (Table 1). Among clients, the prevalence was similar: 133 (25.1\%) were positive for HBV and 7 (1.3\%) positive for HCV. Active HBV, as evidenced by a positive $\mathrm{HBs} A g$, was present in $1.9 \%$ of barbers and $1.7 \%$ of clients.

The mean ages of barbers and clients were 41 and 43 years respectively. The majority of study participants (69.9\%) were illiterate or had only completed primary school education, and most (94.2\%) had low socioeconomic status, earning less than 1500 dirhams per month. The majority (56.6\%) of barbershops were located in a rural setting (Table 2).

Information about barber shop characteristics and shaving practices was collected by direct observation for 546 subjects. New razors were used 96.3\% of the time (Table 3 ).

\section{Knowledge and beliefs about $\mathrm{HBV}$ and $\mathrm{HCV}$ and their transmission}

Among barbers and clients combined, $539 / 796$ (67.7\%) were familiar with jaundice as a sign of liver disease. Less than $1 \%$ of barbers had heard of HBV or HCV infection. Those familiar with viral hepatitis reported that their main information sources about this disease were word of mouth (38.1\%), television (20.0\%), radio (8.7\%) and, less commonly, print media (2.0\%). Almost all the study participants (barbers and their clients) (97.0\%) did not know the modes of transmission of viral hepatitis. Among clients, 100\% reported that they insisted that barbers use new blades but $47.1 \%$ reported trusting the other shaving conditions to the barber.

\section{Risk factors for HBV and HCV}

Among traditional barbers and their clients, the odds of HBV seropositivity were higher in individuals with the following characteristics: age $>45$ years, low educational level, urban address, married status, history of blood transfusion, not currently in a heterosexual relationship (with wife or girlfriend) and symptoms of liver disease (Table 4). In the final multivariable model, adjusting for history of surgery or recent dental procedures, increased age (OR 1.63, 95\% CI: 1.29-2.06), urban living (OR 1.47, 95\% CI: 1.12-1.92) and lack of current heterosexual relationship (OR 1.59, 95\% CI: 1.09-2.31) were independent risk factors for hepatitis B.

Observation of barber's shop characteristics and shaving techniques is shown in Table 3. In a multivariate model, after adjusting for use of a new razor, barbers still had a lower risk of HBV with use of alum as an antiseptic (RR 0.81, 95\% CI: 0.30-0.92) and in well-decorated shops (RR 0.44, 95\% CI: $0.21-0.89$ ).

In univariate analyses, HCV was associated with increased age and low level of education (Table 5). Multivariate analysis could not be performed due to the small number of subjects with positive $\mathrm{HCV}$.

Surprisingly, observations showed that the use of disinfectant on cuts was associated with increased risk of $\mathrm{HCV}$ seropositivity (RR 7.71); other barber practices and shop conditions were not statistically significantly associated with $\mathrm{HCV}$ in the univariate analyses (Table 3).

\begin{tabular}{|c|c|c|c|c|c|c|}
\hline \multirow[t]{2}{*}{ Positivity } & \multicolumn{2}{|c|}{ Barbers } & \multicolumn{2}{|c|}{ Clients } & \multirow[t]{2}{*}{$\operatorname{RR}(95 \% \mathrm{Cl})$} & \multirow[t]{2}{*}{$P$-value ${ }^{a}$} \\
\hline & $\begin{array}{l}\text { No. of } \\
\text { cases }\end{array}$ & $\%$ & $\begin{array}{l}\text { No. of } \\
\text { cases }\end{array}$ & $\%$ & & \\
\hline $\mathrm{HBsAg}$ and anti-HBc & 5 & 1.9 & 9 & 1.7 & $1.10(0.37-3.25)$ & 0.86 \\
\hline Anti-HBs and anti-HBc & 28 & 10.5 & 63 & 11.9 & $0.88(0.57-1.34)$ & 0.55 \\
\hline Only anti-HBc & 61 & 22.8 & 112 & 21.2 & $1.07(0.81-1.42)$ & 0.58 \\
\hline Only anti-HBs & 42 & 15.7 & 83 & 15.7 & $1.00(0.71-1.40)$ & 0.98 \\
\hline HBV seropositive & 75 & 28.1 & 133 & 25.1 & $1.11(0.87-1.42)$ & 0.37 \\
\hline HCV seropositive & 3 & 1.1 & 7 & 1.3 & $0.84(0.22-3.25)$ & 0.81 \\
\hline
\end{tabular}

${ }^{a}$ Chi-squared test.

$R R=$ relative risk; $C I=$ confidence interval.

$H B s A g=$ hepatitis $B$ surface antigen; anti-HBC= hepatitis B core antibody; anti-HBs = hepatitis $B$ surface antibody; HBV=hepatitis B virus; $H C V=$ hepatitis $C$ virus. 


\begin{tabular}{|c|c|c|c|c|c|c|}
\hline \multirow[t]{2}{*}{ Characteristic } & \multicolumn{2}{|c|}{ Barbers } & \multicolumn{2}{|c|}{ Clients } & \multicolumn{2}{|c|}{ Totala $^{a}$} \\
\hline & No. & $\%$ & No. & $\%$ & No. & $\%$ \\
\hline \multicolumn{7}{|l|}{ Age (years) } \\
\hline $15-29$ & 89 & 33.6 & 157 & 30.8 & 246 & 31.8 \\
\hline $30-44$ & 83 & 31.3 & 132 & 25.9 & 215 & 27.8 \\
\hline $45-75$ & 93 & 35.1 & 220 & 43.2 & 313 & 40.4 \\
\hline \multicolumn{7}{|l|}{ Level of education } \\
\hline University & 4 & 1.5 & 9 & 1.7 & 13 & 1.7 \\
\hline Secondary & 89 & 34.2 & 133 & 25.5 & 222 & 28.4 \\
\hline Primary & 52 & 20.0 & 93 & 17.9 & 145 & 18.6 \\
\hline No education & 115 & 44.2 & 286 & 54.9 & 401 & 51.3 \\
\hline \multicolumn{7}{|l|}{ Area of residence } \\
\hline Urban & 37 & 14.0 & 51 & 9.9 & 88 & 11.3 \\
\hline Suburban & 87 & 33.0 & 164 & 31.7 & 251 & 32.1 \\
\hline Rural & 140 & 53.0 & 302 & 58.4 & 442 & 56.6 \\
\hline \multicolumn{7}{|l|}{ Marital status } \\
\hline $\begin{array}{l}\text { Unmarried/ } \\
\text { divorced }\end{array}$ & 90 & 34.0 & 165 & 32.5 & 255 & 33.0 \\
\hline Married & 175 & 66.0 & 343 & 67.5 & 518 & 67.9 \\
\hline \multicolumn{7}{|l|}{ Monthly income } \\
\hline$<$ US\$150 & 202 & 97.6 & 370 & 92.5 & 572 & 94.2 \\
\hline$\geq$ US\$ 150 & 5 & 2.4 & 30 & 7.5 & 35 & 5.8 \\
\hline
\end{tabular}

${ }^{a}$ Data missing in some categories.

\section{Discussion}

The prevalence of HBV and HCV infection varies from country to country and even from one region to another, depending on environmental factors and host characteristics. The prevalence of $\mathrm{HBV}$ and $\mathrm{HCV}$ has been widely investigated in many occupational groups, but relatively few data are available on the prevalence in barbers who regularly come into contact with blood and body fluids of clients and may be expected to have an elevated risk of exposure to bloodborne pathogens $[15,16]$. In our study, $28.1 \%$ of traditional barbers and $25.1 \%$ of their clients had evidence of current or past $\mathrm{HBV}$ infection (all were unvaccinated against $\mathrm{HBV}$ ), $1.9 \%$ and $1.7 \%$ respectively had active $\mathrm{HBV}$ and $1.1 \%$ of barbers and $1.3 \%$ of clients had chronic HCV. Our study corroborates a previous study in Casablanca in Morocco, in 2001 , which showed that $2 \%$ of and Italy showing an increased risk of $\mathrm{HBV}$ among traditional barbers or their clients $[9,15,17,18]$. HBV seropositivity among barbers and clients aged 45-70 years was significantly higher than among younger age groups. Higher rates of $\mathrm{HBV}$ in older individuals probably reflect the increased time at risk for the disease over a lifetime.

The HCV seropositivity rates in our study were similar to the prevalence in the general population in Morocco [13]. This seroprevalence is significantly lower than that found by ZahraouiMahadji et al. in Casablanca (5\%) [2] and among barbers elsewhere $[11,17]$. Individuals giving or receiving traditional barber services have been shown to be at higher risk of $\mathrm{HCV}$ in most, but not all, settings $[6,7,10,12,19]$. In spite of the poor hygiene conditions in many barbershops in this study, we observed a near-universal practice of changing of blades between clients. In Janjua et al.'s study $45.8 \%$ of Pakistani barbers reused razors, presumably contributing to the dissemination of the virus [20]. It is unclear how long using new blades for each client has been a routine part of shaving practices in Morocco. However, the spread of HCV can be promoted by the sharing of razor blades within families or by using instruments cleaned only by antiseptics that do not destroy HCV [14]. Attention to sterility of blades for facial shaving is clearly crucial.

Knowing that traditional barbers and their clients may be at higher risk for $\mathrm{HBV}$ or $\mathrm{HCV}$ is useful information from a public health standpoint, and identifying additional risk factors for $\mathrm{HBV}$ and $\mathrm{HCV}$ in these groups may further inform strategies to minimize the incidence of these diseases in the population. Our analysis showed that older age, urban living and lack of a current heterosexual relationship were risk factors for HBV. The associations between some factors, such as marriage or low educational status, and HBV in univariate analyses, were likely confounded by 


\begin{tabular}{|c|c|c|c|c|c|c|c|c|c|}
\hline \multirow[t]{2}{*}{ Variable } & \multirow{2}{*}{$\begin{array}{l}\text { Total by } \\
\text { category }\end{array}$} & \multicolumn{4}{|c|}{ HBV risk factors } & \multicolumn{4}{|c|}{ HCV risk factors } \\
\hline & & $\begin{array}{c}\text { HBV } \\
\text { positive }\end{array}$ & $\%$ & $\operatorname{RR}(95 \% \mathrm{Cl})$ & $P$-value ${ }^{\text {a }}$ & $\begin{array}{c}\text { HCV } \\
\text { positive }\end{array}$ & $\%$ & $\mathbf{R R}(95 \% \mathrm{Cl})$ & $P$-value ${ }^{b}$ \\
\hline \multicolumn{10}{|c|}{ Barber shaving practices } \\
\hline \multicolumn{10}{|c|}{ Washes the razor with antiseptic solution } \\
\hline Yes & 234 & 53 & 22.6 & \multirow{2}{*}{$1.00(0.73-1.38)$} & \multirow{2}{*}{0.99} & 5 & 2.1 & \multirow{2}{*}{$2.03(0.48-8.40)$} & \multirow{2}{*}{0.26} \\
\hline No & 283 & 64 & 22.6 & & & 3 & 1.1 & & \\
\hline \multicolumn{10}{|c|}{ Uses a new razor for each client } \\
\hline Yes & 502 & 109 & 21.7 & \multirow{2}{*}{$0.55(0.33-1.27)$} & \multirow{2}{*}{0.25} & 7 & 1.4 & \multirow{2}{*}{-} & \multirow{2}{*}{0.78} \\
\hline No & 18 & 6 & 33.3 & & & 0 & 0.0 & & \\
\hline \multicolumn{10}{|c|}{ Sterilizes instruments properly } \\
\hline Yes & 309 & 68 & 22.0 & \multirow{2}{*}{$1.04(0.72-1.46)$} & \multirow{2}{*}{0.86} & 2 & 0.6 & \multirow{2}{*}{$0.39(0.06-2.34)$} & \multirow{2}{*}{0.26} \\
\hline No & 183 & 39 & 21.3 & & & 3 & 1.6 & & \\
\hline \multicolumn{10}{|c|}{ Uses alum as antiseptic for skin cuts } \\
\hline Yes & 407 & 83 & 20.4 & \multirow{2}{*}{$0.56(0.45-0.93)$} & \multirow{2}{*}{0.02} & 6 & 1.5 & \multirow{2}{*}{$1.31(0.16-11.1)$} & \multirow{2}{*}{0.63} \\
\hline No & 89 & 28 & 31.5 & & & 1 & 1.1 & & \\
\hline \multicolumn{10}{|c|}{ Disinfects skin cuts properly } \\
\hline Yes & 123 & 33 & 26.8 & \multirow{2}{*}{$1.45(0.92-1.89)$} & 012 & 5 & 4.1 & 771 (146-279) & 0.01 \\
\hline No & 366 & 74 & 20.2 & & 0.12 & 2 & 0.5 & $1.11(1.40-3 / .9)$ & 0.01 \\
\hline Barbersh & teristics & & & & & & & & \\
\hline Shop sitt & n open-air & market ar & & & & & & & \\
\hline Yes & 346 & 97 & 28.0 & $192(116-237)$ & $0 \cap 04$ & 6 & 1.7 & $344(041-280)$ & 027 \\
\hline No & 196 & 33 & 16.8 & $1.92(1.10-2.3 /)$ & 0.004 & 1 & 0.5 & $0.44(0.41-20.0)$ & 0.21 \\
\hline Shop cle & & & & & & & & & \\
\hline Yes & 204 & 31 & 15.2 & $042(035-073)$ & -0001 & 1 & 0.5 & (בר 1 רח & 012 \\
\hline No & 341 & 102 & 29.9 & $0.42(0.35-0.73)$ & $<0.001$ & 7 & 2.1 & $0.23(0.02-1.92)$ & 0.13 \\
\hline Shop de & d attractiv & & & & & & & & \\
\hline Yes & 95 & 13 & 13.7 & $045030-088)$ & 001 & 1 & 1.1 & $066(008-535)$ & 0.57 \\
\hline No & 443 & 116 & 26.2 & $0.450 .30-0.001$ & & 7 & 1.6 & & \\
\hline Shop wit & athing faci & lities & & & & & & & \\
\hline Yes & 158 & 26 & 16.5 & $052(040090)$ & ( & 2 & 1.3 & $078(016 \quad 285)$ & 056 \\
\hline No & 373 & 102 & 27.3 & $0.52(0.40-0.00)$ & 0.007 & 6 & 1.6 & $0.10(0.16-3.03)$ & 0.56 \\
\hline Shop wit & te sinkfor & washing $h$ & ands $a$ & face & & & & & \\
\hline Yes & 160 & 26 & 16.3 & $060(040-890)$ & ( & 1 & 0.6 & $030(0.04-271)$ & 022 \\
\hline No & 375 & 101 & 26.9 & $0.00(0.40-0.03)$ & 0.000 & 6 & 1.6 & $0.57(0.04-2.21)$ & 0.02 \\
\hline
\end{tabular}

${ }^{a}$ Chi-squared test; ${ }^{b}$ Fisher test/corrected Yates.

$R R=$ relative risk; $C I=$ confidence interval; $-=$ undefined

age and were not statistically significant in the multivariate model. Interestingly, in our study, being in a current heterosexual relationship was protective against $\mathrm{HBV}$, perhaps because this group largely consisted of married men at low risk of sexual acquisition of HBV. Risk factors for HCV included, not surprisingly, drug use, history of surgery and older age.
One key goal of the present study was to assess knowledge about hepatitis and its mode of transmission. Our study suggests that traditional barbers and their clients in Morocco are unfamiliar with HBV and HCV and are mostly unaware of the transmission of bloodborne pathogens through shaving tools. Since the majority of infections with $\mathrm{HBV}$ or $\mathrm{HCV}$ are asymptomatic, this is not a surprising finding. Asymptomatic carriage, however, brings a high risk of primary liver cancer and chronic active hepatitis, which can progress to cirrhosis or death $[21,22]$. Increased awareness of the risks of unsterile facial shaving practices would help both barbers and their customers avoid this unnecessary but potentially life-threatening risk. 


\begin{tabular}{|c|c|c|c|c|}
\hline \multirow[t]{2}{*}{ Variable } & \multicolumn{2}{|c|}{ HBV positive } & \multirow[t]{2}{*}{$\mathrm{OR}^{\mathrm{a}}(95 \% \mathrm{CI})^{\mathrm{a}}$} & \multirow[t]{2}{*}{$P$-value ${ }^{a}$} \\
\hline & No. of cases & $\%$ by risk category & & \\
\hline \multicolumn{5}{|l|}{ Age (years) } \\
\hline $15-29$ & 40 & 16.3 & 1.00 & \multirow{3}{*}{$<0.001^{\mathrm{b}}$} \\
\hline $30-44$ & 53 & 24.7 & $1.68(1.04-2.74)$ & \\
\hline $45-70$ & 110 & 35.1 & $2.79(1.82-4.30)$ & \\
\hline \multicolumn{5}{|l|}{ Level of education } \\
\hline University & 4 & 30.8 & \multirow{4}{*}{$0.74(0.62-0.69)$} & \multirow{4}{*}{0.002} \\
\hline Secondary & 40 & 18.0 & & \\
\hline Primary & 37 & 25.5 & & \\
\hline No education & 123 & 3.7 & & \\
\hline \multicolumn{5}{|l|}{ Area of residence } \\
\hline Urban & 37 & 42.0 & \multirow{3}{*}{$1.22(0.97-1.53)$} & \multirow{3}{*}{0.087} \\
\hline Suburban & 52 & 20.7 & & \\
\hline Rural & 115 & 26.0 & & \\
\hline \multicolumn{5}{|l|}{ Marital status } \\
\hline Unmarried or divorced & 50 & 19.6 & \multirow{2}{*}{$1.72(1.19-2.47)$} & \multirow{2}{*}{0.003} \\
\hline Married & 153 & 29.5 & & \\
\hline \multicolumn{5}{|l|}{ Smoking } \\
\hline Yes & 94 & 24.1 & \multirow{2}{*}{$0.81(0.59-1.12)$} & \multirow{2}{*}{0.20} \\
\hline No & 113 & 28.0 & & \\
\hline \multicolumn{5}{|l|}{ Alcohol use } \\
\hline Yes & 48 & 22.2 & \multirow{2}{*}{$0.75(0.52-1.08)$} & \multirow{2}{*}{0.12} \\
\hline No & 157 & 27.7 & & \\
\hline \multicolumn{5}{|l|}{ Drug use } \\
\hline Yes & 17 & 18.3 & \multirow[t]{2}{*}{$0.61(0.35-1.06)$} & \multirow[t]{2}{*}{0.08} \\
\hline No & 181 & 26.8 & & \\
\hline History of blood transfusio & & & & \\
\hline Yes & 56 & 32.6 & & \\
\hline No & 147 & 24.7 & $1.46(1.01-2.12)$ & 0.04 \\
\hline Used traditional healer & & & & \\
\hline Yes & 47 & 30.7 & $135(092-200)$ & 012 \\
\hline No & 144 & 24.7 & $1.35(0.92-2.00)$ & 0.12 \\
\hline History of past surgery & & & & \\
\hline Yes & 73 & 29.2 & & \\
\hline No & 29 & 24.4 & $1.28(0.91-1.79)$ & 0.15 \\
\hline History of dental procedur & & & & \\
\hline Yes & 123 & 25.8 & $0.99(0.71-1.38)$ & 0.95 \\
\hline No & 74 & 26.0 & $0.99(0.7-1.38)$ & 0.95 \\
\hline Current heterosexual relati & & & & \\
\hline Yes & 80 & 19.8 & & \\
\hline No & 106 & 31.1 & $0.54(0.39-0.76)$ & $<0.001$ \\
\hline Symptoms of liver disease & & & & \\
\hline Yes & 28 & 36.8 & $176(107-290)$ & 0025 \\
\hline No & 170 & 24.9 & $1 . / 6(1.0 /-2.90)$ & 0.025 \\
\hline
\end{tabular}

${ }^{a}$ Logistic regression analysis (global model); ${ }^{b}$ Chi-squared test for linear trend.

$O R=$ odds ratio; $C I=$ confidence interval. 


\begin{tabular}{|c|c|c|c|c|}
\hline \multirow[t]{2}{*}{ Variable } & \multicolumn{2}{|c|}{ HCV positive } & \multirow[t]{2}{*}{$\operatorname{RR}^{\mathrm{a}}(95 \% \mathrm{Cl})^{\mathrm{a}}$} & \multirow[t]{2}{*}{$P$-value ${ }^{b}$} \\
\hline & No. of cases & \% by risk category & & \\
\hline \multicolumn{5}{|l|}{ Age (years) } \\
\hline 15-29 & 1 & 0.4 & 1.00 & \multirow[t]{3}{*}{$0.002^{\mathrm{c}}$} \\
\hline $30-44$ & 1 & 0.5 & $1.14(0.07-18.2)$ & \\
\hline $45-70$ & 8 & 2.6 & $6.29(0.79-49.9)$ & \\
\hline \multicolumn{5}{|l|}{ Level of education } \\
\hline University & 0 & 0.0 & 1.00 & \multirow[t]{4}{*}{$0.03^{c}$} \\
\hline Secondary & 0 & 0.0 & - & \\
\hline Primary & 2 & 1.4 & - & \\
\hline No education & 8 & 2.0 & - & \\
\hline \multicolumn{5}{|l|}{ Area of residence } \\
\hline Urban & 0 & 0.0 & 1.00 & \multirow[t]{3}{*}{$0.15^{\mathrm{c}}$} \\
\hline Suburban & 2 & 0.8 & - & \\
\hline Rural & 7 & 1.6 & - & \\
\hline \multicolumn{5}{|l|}{ Marital status } \\
\hline Unmarried or divorced & 2 & 0.8 & \multirow{2}{*}{$1.73(0.36-8.40)$} & \multirow{2}{*}{0.49} \\
\hline Married & 7 & 1.4 & & \\
\hline \multicolumn{5}{|l|}{ Monthly income } \\
\hline$<$ US\$150 & 8 & 1.4 & \multirow{2}{*}{-} & \multirow{2}{*}{0.95} \\
\hline$\geq$ US\$ 150 & 0 & 0.0 & & \\
\hline \multicolumn{5}{|l|}{ Smoking } \\
\hline Yes & 5 & 1.3 & \multirow{2}{*}{$1.03(0.29-3.59)$} & \multirow{2}{*}{0.95} \\
\hline No & 5 & 1.2 & & \\
\hline \multicolumn{5}{|l|}{ Drink alcohol } \\
\hline Yes & 1 & 0.5 & \multirow{2}{*}{$0.29(0.03-2.29)$} & \multirow{2}{*}{0.24} \\
\hline No & 9 & 1.6 & & \\
\hline \multicolumn{5}{|l|}{ Drug use } \\
\hline Yes & 3 & 3.2 & 371 (092-151) & 006 \\
\hline No & 6 & 0.9 & (1) & 0.00 \\
\hline History of transfusion & & & & \\
\hline Yes & 1 & 0.6 & $0.49(0.06-4.00)$ & 0.50 \\
\hline No & 7 & 1.2 & $0.45(0.00-4.00)$ & 0.00 \\
\hline Traditional healer & & & & \\
\hline Yes & 2 & 1.3 & $095(020-454)$ & 073 \\
\hline No & 8 & 1.4 & $0.93(0.20-4.34)$ & 0.13 \\
\hline History of surgery & & & & \\
\hline Yes & 6 & 2.4 & $322(0.90-125)$ & 0.07 \\
\hline No & 4 & 0.8 & $3.22(0.00-12.0)$ & \\
\hline History of dental procedur & & & & \\
\hline Yes & 5 & 1.0 & $059(017-207)$ & 0.41 \\
\hline No & 5 & 1.8 & $0.07(0.17-2.07)$ & 0.41 \\
\hline Current heterosexual relat & & & & \\
\hline Yes & 3 & 0.7 & $049(011-209)$ & 034 \\
\hline No & 5 & 1.5 & (1) & 0.07 \\
\hline Symptoms of liver disease & & & & \\
\hline Yes & 3 & 3.9 & $397(101-157)$ & 0,049 \\
\hline No & 7 & 1.0 & $3.97(1.01-15 . /)$ & 0.049 \\
\hline
\end{tabular}

${ }^{a}$ Chi-squared test; ${ }^{b}$ Fisher test/corrected Yates, . ${ }^{c}$ Chi-squared test for linear trend $R R=$ relative risk; $C I=$ confidence interval; $-=$ undefined. 
Facial shaving from barbers has been repeatedly documented as a risk factor for transmission of HBV and HCV in various countries and is well known to cause abrasions and small cuts [23]. When it is done with unsterilized instruments, such as razors or scissors, it can spread bloodborne pathogens $[7,24]$. According to the observed practices in our study, barbers changed blades for each client. However, barbers had a poor understanding of the processes necessary for complete sterilization of used instruments. Thus, if new blades are not consistently used, as may be the case when barbers are not being observed by a research team, the risk of contamination is still present. Consequently, using alum for disinfecting skin cuts further increases shaving safety. This study also showed that there was a significant association between a lower risk of viral hepatitis and the neatness and cleanliness of the barbershop, as has been demonstrated in other studies $[16,25]$. These shop characteristics may be markers for overall attention to cleanliness and sterility that extends to shaving instruments and practices.

Our study had several limitations. We were unable to do a multivariable logistic regression for risk factors for $\mathrm{HCV}$ because of the small number of cases. Given the low prevalence of hepatitis C in Morocco, a case-control study may be a good way to look at risk factors for $\mathrm{HCV}$, as has been done by investigators in other settings [7]. Also, barbers may change their behaviour when they know a researcher is watching, so changing blades before each client may be less than $100 \%$ in real practice conditions.

In conclusion, current or past infection with HBV (and less commonly $\mathrm{HCV}$ ) is frequent among barbers and their clients in Morocco, particularly among those over 45 years of age. Despite this, few people were aware of the risk posed by unsafe shaving practices. For these reasons, awareness campaigns are imperative and should be focused on both barbers and the general population. Because barbers are sometimes engaged in other traditional practices such as circumcision, dentistry and bloodletting, educating barbers about the health risks of HBV and HCV and strategies for minimizing risk of transmission of bloodborne pathogens can help reduce transmission of $\mathrm{HBV}$ and HCV both inside and outside the barber shop.

\section{Acknowledgements}

This study received technical and financial support from the WHO Eastern Mediterranean Regional Office's (EMRO) Special Programme for Research and Training in Tropical Diseases (TDR). We are indebted to Dr O. Bennani, Dr R. Mengad, Dr A. Siwani, Mr A. Laskri and Mrs Z. Soutouri from the National Institute for Hygiene for assisting with sample collection and questionnaire application. We also thank Mr Chettahi from the Health Delegation of Khemisset province for his helpful assistance during the field investigation.

\section{References}

1. Hepatitis C. Fact sheet no. 164. Geneva, World Health Organization, 2000 (https://apps.who.int/inf-fs/en/fact164.html, accessed 23 October 2011).

2. Hepatitis B. Fact sheet no. 204. Geneva, World Health Organization, 2000 https://apps.who.int/inf-fs/en/fact204.html, accessed 23 October 2011).

3. Lee W. Hepatitis B virus infection. New England Journal of Medicine, 1997, 337:1733-1745.

4. Zuckerman JN, Zuckerman AJ. Current topics in hepatitis B. Journal of Infection, 2000, 41:130-136.

5. Gitlin N. Hepatitis B: diagnosis, prevention and treatment. Clinical Chemistry, 1997, 43:1500-1506.

6. Junjua NZ et al. Health care risk factors among women and personal behaviours among men explain the high prevalence of hepatitis C virus infection in Karachi, Pakistan. Journal of Viral Hepatitis, 2009, 17(5):317-326.

7. Makheja KD, Abro AH, Kumar S. Sero-prevalence of hepatitis $\mathrm{C}$ antibodies in the people visiting roadside barbers. Pakistan Journal of Medical Sciences, 2010, 26:402-406.

8. Nuchprayoon T, Chumnijarakij T. Risk factors for hepatitis B carrier status among blood donors of the National Blood Center, Thai Red Cross Society. Southeast Asian Journal of Tropical Medicine and Public Health, 1992, 23:246-253.

9. Paez Jimenez $\mathrm{A}$ et al. Community transmission of hepatitis B virus in Egypt: results from a case-control study in Greater Cairo. International Journal of Epidemiology, 2009, 38:757-765.
10. Qureshi H et al. Determination of risk factors for hepatitis B and $\mathrm{C}$ in male patients suffering from chronic hepatitis. $B M C$ Research Notes, 2009, 2:212.

11. Shalaby $S$ et al. Hepatitis B and C viral infection: prevalence, knowledge, attitude and practice among barbers and clients in Gharbia governorate, Egypt. Eastern Mediterranean Health Journal, 2010, 16(1):10-17.

12. Thakral $B$ et al. Prevalence and significance of hepatitis $C$ virus (HCV) seropositivity in blood donors. Indian Journal of Medical Research, 2006, 124:431-438.

13. Boutayeb H, Aamoum A, Benchemsi N. [Knowledge about hepatitis $B$ and $C$ viruses and HIV among blood donors in Casablanca.] Connaissances sur les virus des hepatites B et $\mathrm{C}$ et le VIH chez des donneurs de sang à Casablanca. Eastern Mediterranean Health Journal, 2006, 12(5):538-547.

14. Zahraoui-Mehadji $M$ et al. Infectious risks associated with blood exposure for traditional barbers and their customers in Morocco. Santé (Montrouge, France), 2004, 14:211-216.

15. She SL et al. A seroepidemiologic study of hepatitis B virus infection among barbers in Huangshi city, Hubei, China. Microbiology and Immunology, 1988, 32:229-233.

16. Tummenelli $F$ et al. Shaving as potential source of hepatitis $C$ virus infection [letter]. Lancet, 1995, 327:658.

17. Candan $\mathrm{F}$ et al. Prevalence of hepatitis $\mathrm{B}$ and $\mathrm{C}$ virus infection in barbers in the Sivas region of Turkey. Occupational Medicine (Oxford, England), 2002, 52:31-34. 
18. Mariano A et al. Role of beauty treatment in the spread of parenterally transmitted hepatitis viruses in Italy. Journal of Medical Virology, 2004, 74:216-220.

19. Sawayama $Y$ et al. Hepatitis $C$ virus infection in institutionalized psychiatric patients: possible role of transmission by razor sharing. Digestive Diseases and Sciences, 2000, 45:351-356.

20. Janjua NZ, Nizamy MA. Knowledge and practices of barbers about hepatitis B and C transmission in Rawalpindi and Islamabad. Journal of the Pakistan Medical Association, 2004, 54:116-119.

21. Esteban Jl et al. Molecular biology, pathogenesis, epidemiology, clinical features, and prevention. Progress in Liver Diseases, 1992, 10:253-282.
22. Francisci D et al. Risk factors for acute parentally transmitted viral hepatitis: a 20 year study. European Journal of Epidemiology, 1993, 9:625-628.

23. Shapiro CN. Transmission of hepatitis viruses. Annals of Internal Medicine, 1994, 120:82-84.

24. Khaliq AA, Smego RA. Barber shaving and blood-borne disease transmission in developing countries. South African Medical Journal, 2005, 95:94-96.

25. Mele A et al. Beauty treatments and risk of parenterally transmitted hepatitis. Results from the hepatitis surveillance system in Italy. Scandinavian Journal of Infectious Diseases, 1995, 27:441-444.

\section{Hepatitis B and C key facts}

\section{Hepatitis B}

Hepatitis B is a liver disease caused by the hepatitis B virus (HBV).

$\mathrm{HBV}$ is transmitted through contact with the blood or other body fluids (i.e. semen and vaginal fluid) of an infected person, by for example unsafe injection practices, blood transfusions and sexual contact.

Hepatitis B is not spread through food or water or by casual contact with an infected person.

About 2 billion people worldwide have been infected with $\mathrm{HBV}$ and about 350 million live with chronic infection. Around 600000 people die each year due to the consequences of hepatitis B.

Chronic hepatitis B can be treated with drugs, including interferon and anti-viral medications.

Hepatitis B is preventable with a safe and effective vaccine.

Source: WHO Fact sheets No. 204 and No. 164

\section{Hepatitis C}

Hepatitis $\mathrm{C}$ is a liver disease caused by the hepatitis $\mathrm{C}$ virus (HCV).

$\mathrm{HBC}$ is most commonly transmitted through exposure to infectious blood. It can be transmitted through sex with an infected person and sharing personal items contaminated with infectious blood.

Hepatitis $C$ is not spread through food or water or by casual contact with an infected person.

About 130-170 million people worldwide are chronically infected with $\mathrm{HCV}$, and more than 350000 people die from hepatitis C-related liver diseases each year.

$\mathrm{HCV}$ infection is curable using increasingly effective antiviral medications.

There is currently no vaccine to prevent hepatitis $C$ virus infection. 